\title{
HIGH BLOOD GLUCOSE LEVEL INCREASE CARDIOVASCULAR DISEASE RISK IN TYPE 2 DIABETES MELLITUS
}

\author{
Laili Zahrina Marchelia ${ }^{1}$, Purwati ${ }^{2}$, Rio Wironegoro ${ }^{2}$ \\ ${ }^{1}$ International Class of Medical Faculty of Universitas Airlangga \\ ${ }^{2}$ Internal Medicine Department of Medical Faculty of Universitas Airlangga
}

\begin{abstract}
ABSTRAK
Diabetes Mellitus (DM) Tipe 2 penyebab kematian yang kesepuluh di dunia dan penderita DM memiliki risiko 4.06 kali lebih tinggi untuk mengalami penhakit kardiovaskular. Kadar gula darah puasa dan gula adarah 2 jam setelah makan merupakan sarana diagnostik untuk mengevaluasi penyakit DM serta sebagai faktor prediktif terkait penyakit kardiovaskular. Penelitian ini menggunakan metode analitik deskriptif dengan desain cross sectional. Subjek dari penelitian ini adalah penderita DM tipe 2 yang datang ke RSUD Dr Soetomo dalam kurun waktu bulan Januari-Oktober 2014. Data didapatkan melalui rekam medis penderita dan dianalisis menggunakan tes Chi Square dengan nilai P<0,05. Hasilnya, didapatkan 102 penderita DM tipe 2 dimana 36 penderita memiliki manifestasi penyakiy kardiovaskular dan 66 penderita tidak ditemukan komplikasi apapun. Didapatkan asosiasi yang signifikan antara kadar gula puasa, kadar gula 2 jam setelah makan dengan manifestasi penyakit kardiovaskular (p=0,00). Jadi, kadar gula puasa dan kadar gula 2 jam setelah makan memiliki asosiasi yang signifikan dengan manifestasi penyakit kardiovaskular. Didapatkan faktor-faktor lain yang mempengaruhi timbulnya penyakit kardiovaskular sehingga perlu dilakukan penelitian lebih lanjut terkait hal tersebut. (FMI 2016;52:127-130)
\end{abstract}

Kata kunci: Diabetes Mellitus Tipe 2, penyakit kardiovaskular, gula darah puasa, gula darah 2 jam setelah makan.

\begin{abstract}
Type 2 diabetes mellitus (DM) is the 10th leading cause of death in the world and had a risk 4.06 times greater to have cardiovascular disease (CVD). Fasting plasma glucose and 2-hours postprandial glucose level as diagnostic tests to evaluate DM and also as a predictive factors to CVD. This research uses descriptive analytic research with cross sectional design. The subject of this study is Type 2 DM patients came to Dr Soetomo hospital from January-October 2014. Data was recorded from medical records of patients and was analyzed with Chi Square test with $p<0.05$. As result, there is 102 Type 2 DM patients with 36 patients have CVD manifestation and 66 patients without complication. There is a significant association between fasting plasma glucose (FPG), 2hours postprandial glucose (2hPPG) level, and CVD manifestation ( $p=0.00)$. So FPG and $2 h P P G$ have a significant association with CVD manifestation. There are other factors that influencing the formation of CVD, hence, further research is needed. (FMI 2016;52:127-130)
\end{abstract}

Keywords: Type 2 Diabetes Mellitus, cardiovascular disease, fasting plasma glucose, 2-hours postprandial glucose.

Correspondence: Laili Zahrina Marchelia, International Class of Medical Faculty of Universitas Airlangga, Jalan Prof dr Moestopo 47, Surabaya 60131, Indonesia.

\section{INTRODUCTION}

Type 2 diabetes mellitus (DM) is a chronic disease caused by inability to respond properly to the action of insulin produced by the pancreas. DM is the 10th leading cause of death in the world, causing $2.6 \%$ deaths in 2011. The effects of hyperglycemia are divided into macrovascular complications (coronary artery disease, peripheral arterial disease, and stroke) and microvascular complications (diabetic nephropathy, neuropathy, and retinopathy) (Fowler 2008). The results of health research by Ministry of Health in 2007 showed that subjects with diabetes mellitus had a risk 4.06 times higher to have cardiovascular disease than subjects without diabetes mellitus. Many of type 2 DM complications produce no symptoms in the early stages, and most can be prevented or minimized with a combination of routine medical care and blood sugar monitoring. Since the cardiovascular diseases (CVD) are the most common causes of death in these patients, accounting for almost $70 \%$ of the deaths, the prevention of cardiovascular diseases (CVD) is important. In this study, the researcher analyzes the association between Fasting Plasma Glucose (FPG), 2-hours Postprandial Glucose (2hPPG) and cardiovascular disease manifestation in type $2 \mathrm{DM}$ patiens.

\section{MATERIALS AND METHODS}

The study is designed as an analytical study with cross sectional approach to determine the association between 
fasting plasma glucose, 2-hours post prandial plasma glucose level, and cardiovascular disease manifestations using secondary data which is medical records. The data is taken from medical records of Dr. Soetomo hospital. This study is conducted from January to October 2014. Inclusion criteria are patients registered in Dr.Soetomo hospital and Type 2 diabetes mellitus patient whose fasting plasma glucose and 2-hours postprandial glucose level were examined. Exclusion criteria is patients who suffered from DM with other complications except CVD complications. To determine the sample size, formula for nominal data is used and necessary sample size is 79 patients each for FPG level and $2 \mathrm{hPPG}$ level. In this study, 102 patients of each grup are obtained. The FPG is classified into 3 groups, high FPG level $(>126 \mathrm{mg} / \mathrm{dl})$, moderate FPG level $(100-125 \mathrm{mg} / \mathrm{dl})$, and low FPG level $(<100 \mathrm{mg} / \mathrm{dl})$. The $2 \mathrm{hPPG}$ level is classified into 3 groups, high 2PPG level $(>180 \mathrm{mg} / \mathrm{dl})$, moderate $2 \mathrm{hPPG}$ level (144-179 mg/dl), low 2hPPG level $(<144 \mathrm{mg} / \mathrm{dl})$. The CVD manifestation variable data is presented by nominal data, as simple as yes or no. The data is analyzed in descriptive and analytic. The descriptive data with nominal scale is presented in frequencies and percentage, and the descriptive data with numeric scale is presented in mean and deviation standard. Analytical data statistics uses Chi Square hypothesis test. In order to know whether level of FPG and $2 \mathrm{hPPG}$ as a risk factor of CVD, Prevalence Ratio $(\mathrm{PR})$ is used.

\section{RESULTS}

The study was conducted from January to October 2014 in Dr. Soetomo teaching hospital. Samples were taken by consecutive sampling which every patient who met the inclusion criteria is included in the study sample with the minimum required sample size is 79 each group. In this study, 102 samples are taken each from fasting blood glucose group and 2-hours post prandial group. There are 36 people who have complication on CVD and 66 people who do not have complication. Characteristics of the patients can be seen in Table 1 .

Analysis of the data showed there is significant association between both FPG levels, 2hPPG levels and the incidence of cardiovascular disease $(p=0.000)$. The prevalence rate between high, low FPG level and CVD manifestation in type 2 diabetes mellitus patient is 13.1, which means patients with high FPG level have 13.1 times greater risk of having CVD manifestation than patients with low FPG level. Patients with moderate FPG level have risk 2.6 times higher to suffer from CVD manifestation than patients with low FPG level. Majority patient with Type $2 \mathrm{DM}$ in this study is women. Among 102 patients with Type 2 DM, 35.3\% has cardiovascular disease manifestations.

Table 1. Characteristics of the patients with type 2 Diabetes Mellitus

\begin{tabular}{lcc}
\hline Characteristics & DM type 2 & Percentage \\
\hline Sex & & \\
Male & 48 & $47.06 \%$ \\
Female & 54 & $52.94 \%$ \\
Age & & \\
Mean & $55.69 \pm 11.33$ & \\
Median & 55 & Min: 22, \\
Mode & 49 & Max:83 \\
CVD Manifestation & & \\
Yes & 36 & $35.3 \%$ \\
No & 66 & $64.7 \%$ \\
& & \\
\hline
\end{tabular}

Table 2. The Association between FPG, 2hPPG and CVD Manifestations

\begin{tabular}{llll}
\hline & \multicolumn{1}{c}{ CVD $(+)$} & \multicolumn{1}{c}{ CVD $(-)$} & $P$ \\
\hline FPG $(\mathrm{mg} / \mathrm{dL})$ & & & \\
High $(\geq 126)$ & $30(75 \%)$ & $10(25 \%)$ & 0.000 \\
Moderate $(101-125)$ & $4(14.81 \%)$ & $23(85.19 \%)$ & \\
Low $(<100)$ & $2(5.71 \%)$ & $33(94.29 \%)$ & \\
Total & 36 & 66 & \\
Mean FPG & 175.5 & 103.9 & \\
2hPPG (mg/dL) & & & \\
High $(\geq 180)$ & $30(65.22 \%)$ & $16(34.78 \%)$ & 0.000 \\
Moderate $(144-179)$ & $3(13.04 \%)$ & $20(86.96 \%)$ & \\
Low $(<144)$ & $3(9.09 \%)$ & $30(90.9 \%)$ & \\
Total & 36 & 66 & \\
Mean 2hPPG & 253.3 & 149.4 & \\
\hline
\end{tabular}

Table 3. Prevalence Rate FPG, 2hPPG, and CVD Manifestations

\begin{tabular}{|c|c|c|c|c|}
\hline Blood Glucose (mg/dL) & $\begin{array}{c}\text { CVD } \\
(+)\end{array}$ & $\begin{array}{c}\text { CVD } \\
(-)\end{array}$ & PR & $\mathrm{CI}$ \\
\hline \multicolumn{5}{|l|}{ Level of FPG } \\
\hline High $(\geq 126)$ & 30 & 10 & 13.1 & $3.4-51$ \\
\hline Low $(<100)$ & 2 & 33 & & \\
\hline \multicolumn{5}{|l|}{ Level of FPG } \\
\hline Moderate $(100-125)$ & 4 & 23 & 2.6 & $0.5-13.2$ \\
\hline Low $(<100)$ & 2 & 33 & & \\
\hline \multicolumn{5}{|l|}{ Level of $2 \mathrm{hPPG}$} \\
\hline High $(\geq 180)$ & 30 & 16 & 7.2 & \\
\hline Low $(<144)$ & 3 & 30 & & $2.4-21.5$ \\
\hline \multicolumn{5}{|l|}{ Level of $2 \mathrm{hPPG}$} \\
\hline Moderate (145-179) & 3 & 20 & 1.4 & \\
\hline Low $(<144)$ & 3 & 30 & & $0.3-6.5$ \\
\hline
\end{tabular}

The prevalence rate between high, low $2 \mathrm{hPPG}$ level and CVD manifestation in type 2 diabetes mellitus patient is 7.2 , which means patients with high $2 \mathrm{hPPG}$ level have 7.2 times greater risk of having CVD manifestation than patients with low $2 \mathrm{hPPG}$ level. Patients with moderate $2 \mathrm{hPPG}$ level have risk 1.4 times higher to suffer from CVD manifestation than patients with low $2 \mathrm{hPPG}$ level. 
Table 4. Proportion Blood Pressure (BP) and Total Cholesterol Level in Type 2 Diabetes Mellitus Patient to CVD Manifestation

\begin{tabular}{lcc}
\hline Blood Pressure (mmHg) & CVD (+) & CVD (-) \\
\cline { 1 - 2 } Systolic BP & & \\
$<120$ & 13 & 7 \\
$120-139$ & 25 & 8 \\
$\geq 140$ & 28 & 21 \\
Mean (mmHg) & 137.8 & 137.4 \\
\hline Diastolic BP & & \\
$<80$ & 7 & 25 \\
$80-89$ & 16 & 22 \\
$\geq 90$ & 13 & 19 \\
Mean (mmHg) & 85.1 & 81.4 \\
\hline Total Cholesterol (mg/dL) & & \\
$<200$ & 20 & 24 \\
$\geq 200$ & 16 & 42 \\
Mean & 199.9 & 223.1 \\
\hline
\end{tabular}

The average of systolic BP in type 2 diabetes mellitus with CVD complication is $137.4 \mathrm{mmHg}$, and diastolic $\mathrm{BP}$ is $85.1 \mathrm{mmHg}$, and the average of total cholesterol level with is $199.9 \mathrm{mg} / \mathrm{dL}$.

Table 5. Proportion of Type 2 DM patient with and without CVD Manifestation

\begin{tabular}{lcc}
\hline & CVD $(+)$ & CVD (-) \\
\hline Hypertension & & \\
Yes & $21(58.3 \%)$ & $28(42.4 \%)$ \\
No & $15(41.7 \%)$ & $38(57.6 \%)$ \\
Dyslipidemia & & \\
Yes & $16(44.4 \%)$ & $24(36.4 \%)$ \\
No & $20(55.6 \%)$ & $42(63.6 \%)$ \\
\hline
\end{tabular}

Table 6. CVD manifestation in Type 2 Diabetes Mellitus patients

\begin{tabular}{lc}
\hline CVD Manifestations & $\sum$ \\
\hline Myocardial Infarction & $18(50 \%)$ \\
Ischaemic Heart Disease & $7(19.4 \%)$ \\
Ischaemic Cardiomyopathy & $6(16.7 \%)$ \\
Decompensatio Cordis & $4(11.1 \%)$ \\
Stable Angina Pectoris & $1(2.8 \%)$ \\
\hline
\end{tabular}

\section{DISCUSSION}

In this study, type 2 DM patients mostly are women which is 54 of 102 patients (52.94\%), on the same study from Centers of Disease Control (CDC) and American Diabetes Association (ADA) in 2012 stated that Type 2 DM currently affects over 246 million people worldwide and over half of these people are women. While Type 2 DM patients with cardiovascular disease manifestations (CVD) mostly are men which is 20 of 36 (55.6\%). Another study by Færch (2014), stated that men have higher risk of coronary heart disease than women. It may due to estrogen, protective agents for cardiovascular system. Estrogen alters serum lipid concentrations, coagulation and fibrinolytic systems, antioxidant systems, and the production of other vasoactive molecules, such as nitric oxide and prostaglandins, all of which can influence the development of vascular disease (Mendelsohn \& Karas 1999).

We also found that the majority patient diagnosed as Type 2 DM when 49 years old, another study from University of California San Fransisco in 2014 stated that DM type 2 patients are diagnosed in adults over age 40. Stress is one of the risk factors of increasing glucose level, it also gives impact to eating habits, and irregular daily activity. FPG level has association with CVD manifestation. In this study $(\mathrm{p}=0.000)$, among patients with CVD manifestation, they have high FPG level $(>126 \mathrm{mg} / \mathrm{dL})$. It is similar with study done by Park et al (2013), as fasting glucose levels increased to $>100$ $\mathrm{mg} / \mathrm{dL}$, risks for CVD, ischemic heart disease, myocardial infarction, and thrombotic stroke progressively increased. In contrast, patients with low FPG level $(<100 \mathrm{mg} / \mathrm{dL})$ are less to have CVD manifestation. The study by Shimodaira et al (2013), stated that the mean platelet volume (MPV) increased with the increasing FPG levels. MPV can reflect platelet activity, and high MPV is associated with thrombogenic activation and an increased risk of cardiovascular disease.

2hPPG level also associates with CVD manifestations $(\mathrm{p}=0.000)$. Among patients with CVD manifestations, they also have high $2 \mathrm{hPPG}$ level $(>180 \mathrm{mg} / \mathrm{dL})$ and among those without CVD manifestations, they have low $2 \mathrm{hPPG}$ level. According to study by Cavalot et al (2011), the 14-year follow-up of the San Luigi Gonzaga Diabetes Study, supports the conclusion that postprandial blood glucose is not only an essential determinant of $\mathrm{HbAlc}$, but also a relevant tool in cardiovascular events and mortality risk stratification in type 2 diabetes mellitus. Postprandial hyperglycemia may be an independent risk factor for cardiovascular disease in diabetes patients. Hyperglycemia acutely increases the levels of circulating proinflammatory cytokines by an oxidative mechanism. Excessive oxidative stress caused by imbalance between freeradical production and antioxidant response, followed by systemic vascular inflammation, is involved in the pathogenesis of cardiovascular disease in diabetes patients. Postprandial acceleration of oxidative stress and inflammation has been observed in patients with type 2 diabetes. The reduction in carotid intima-media thickness was associated with the improvement of postprandial. Therefore, treating postprandial hyperglycemia may have a positive effect on atherosclerosis progression and cardiovascular diseases (Kitasato et al 2012). 


\section{CONCLUSION}

Both higher FPG and $2 \mathrm{hPPG}$ level results in greater risk of cardiovascular disease manifestation in type 2 diabetes mellitus.

\section{REFERENCES}

Færch K (2014). Gender and T2DM. Available from http://www.diapedia.org/type-2-diabetes-mellitus/ 3104972816/gender-and-t2dm. Accessed November 11, 2014

Fowler MJ (2008). Microvascular and macrovascular complications. Diabetes Foundation 26, 77-81

Kitasato L, Tojo T, Hatakeyama Y, Kameda R, Hashikata T, Yamaoka-Tojo M (2012). Postprandial hyperglycemia and endothelial function in type 2 diabetes: focus on mitiglinide. Cardiovascular Diabetology 11,79

Mannucci E, Dicembrini I, Lauria A, Pozzilli P (2013). Is glucose control important for prevention of cardiovascular disease in diabetes?. Diabetes Care 36, S259-S263
Mendelsohn ME and Karas RH (1999). The protective effects of estrogen on the cardiovascular system. N Engl J Med 340, 1801-1811

Ministry of Health, Republic of Indonesia (2007). Riskesdas, Jakarta, Health Department, Republic of Indonesia

Park C, Guallar E, Linton JA, Lee DC, Jang Y, Son DK, Han EJ, Baek SJ, Yun YD, Jee SH, Samet JM (2013). Fasting glucose level and the risk of incident atherosclerotic cardiovascular diseases. Diabetes Care 36, 1988-1993

Shimodaira M, Niwa T, Nakajima K, Kobayashi M, Hanyu N, Nakayama T (2013). Correlation between mean platelet volume and fasting plasma glucose levels in prediabetic and normoglycemic individuals. Cardiovascular Diabetology 12, 14

Trovati M (2011). Postprandial blood glucose predicts cardiovascular events and all-cause mortality in type 2 diabetes in a 14-year follow-up: lessons from the San Luigi Gonzaga Diabetes Study. Diabetes Care 34, 2237-2243 